\title{
Botulinum Toxin Type B: Where Do We Stand?
}

\author{
Dirk Dressler \\ Department of Neurology, Rostock University, Rostock, Germany
}

Therapeutic use of botulinum toxin type A (BT-A) has dramatically increased after its introduction by Scott [1] in 1980. It now provides help for patients suffering from muscle hyperactivity disorders in neurology, rehabilitation medicine, pediatrics, otorhinolaryngology, ophthalmology, urology and many other areas. Recently, it has been recognised that its cholinergic blockade can also be used to reduce exocrine gland hyperactivity: the longsearched-for remedy for hyperhidrosis. With some evidence suggesting an analgetic effect in tension headache and migraine and with extension of its indications into the fashion world for removal of wrinkles, BT might look almost like a 19th century patent medicine. It certainly sells like one: worldwide BT-A sales soared to mind-boggling US\$ 300 millions or so. Obviously, such a market attracts manufacturers. A new one has just arrived. With his product using botulinum toxin type B (BT-B) botulinum toxin therapy has now taken a new step.

Do we need a new botulinum toxin product? Competition keeps the markets in good shape. With costs of around US\$ 3,000 per year to treat a single torticollis patient vigorous competition is more than welcomed by the health economists.

Do we need a new type of BT? So far, there has been no reason to believe that BT-B will work better than BT-A. With one exception: conventional BT preparations can induce antibody formation. This is a rare phenomenon, occurring in around 5\% of torticollis patients. Not a large number, but, up to now, for most of those patients BT therapy was over. This is where BT-B comes in. Robust studies have demonstrated that BT-A antibodies do not inactivate BT-B [2]. This offers new hope to those patients. But questions remain to be answered: although statistical risk factors have been identified [3], therapy failure cannot be predicted. As a matter of fact, the activity of the individual patient's immune system may well be the key factor. If this is true, antibody formation against BT-B would be imminent, especially given the high structural similarity between BT-B and BT-A. Whether these considerations will transform into a clinical problem we do not know. Only time will tell. When botulinum toxin therapy failure is unrelated to BT-A antibodies BT-B will not help. Reasons for unrelated therapy failure are numerous and considerable clinical experience is needed to identify them.

BT-B cleaves the intracellular transport protein chain at a site different from BT-A [4]. It is not clear whether this matters therapeutically. Studies indicate that in torticollis patients between 7,500 and 10,000 mouse units of BT-B are needed to produce a reasonable therapeutic effect [5]. Similar therapeutic effects are seen after about 150-200 mouse units of Botox ${ }^{\circledR}$ [6] or about 500-750 mouse units of Dysport ${ }^{\circledR}$ [7]. This indicates a conversion factor for Botox ${ }^{\circledR}$ to BT-B in the order of $40-70$ and for

\begin{tabular}{ll}
\hline KARGER & ( ) 2001 S. Karger AG, Basel \\
Fax +41613061234 & $0014-3022 / 01 / 0463-0113 \$ 17.50 / 0$ \\
$\begin{array}{l}\text { E-Mail karger@karger.ch } \\
\text { www.karger.com }\end{array}$ & $\begin{array}{l}\text { Accessible online at: } \\
\text { www.karger.com/journals/ene }\end{array}$
\end{tabular}

Dr. Dirk Dressler

Department of Neurology, Rostock University

Gehlsheimer Strasse 20, D-18147 Rostock (Germany)

Tel. +49 3814949517 , Fax +49 3814949512

E-Mail dirk.dressler@med.uni-rostock.de 
Dysport ${ }^{\circledR}$ to BT-B of 10-20. Without exact data on conversion factors it is very difficult to compare the effectiveness of BT-B and BT-A, the side effect profiles and costs. Going by these conversion factors, BT-B is considerably cheaper than BT-A in some markets. It will be interesting to see future pricing and market share developments there. One mouse unit, the unit for biological potency of all BT preparations, is defined as the amount of BT needed to kill half of a mouse population. If the systems to test this are identical, one mouse unit is the same for BT-A and for BT-B. Why is there so much more BT-B needed to produce a therapeutic effect in torticollis patients? We do not know, but we know that the answer would be very interesting, indeed. One speculation is that there might be less BT-B than BT-A acceptors on the neuromuscular junction [8]. Another immunological issue arises here: one of the risk factors for antibody formation is the protein load [3]. If larger doses of BT-B than of BT-A are needed, the risk of antibody formation should be higher than in BT-A. Again, whether this is relevant in a clinical setting needs to be studied. A reliable and quantitative BT-B antibody test is crucial to investigate these questions. It is, however, not available yet.

Registration studies [5] have shown that BT-B treatment of cervical dystonia produces substantially more often a dry mouth than BT-A. Not a dramatic side effect, but, again, an extremely interesting phenomenon. Does BT-B have a higher affinity to the autonomic nervous system?

We welcome BT-B. It will stimulate competition in the BT market. It also offers new hope to patients with BT-A antibodies. In other patients time will tell whether it has superior, similar or inferior features compared to BT-A.

\section{References}

1 Scott AB: Botulinum toxin injection into extraocular muscles as an alternative to strabismus surgery. J Pediatr Ophthalmol Strabismus 1980;17:21-25.

2 Brin MF, Lew MF, Adler CH, Comella CL, Factor SA, Jankovic J, O'Brien C, Murray JJ, Wallace JD, Willmer-Hulme A, Koller M: Safety and efficacy of NeuroBloc (botulinum toxin type B) in type A-resistant cervical dystonia. Neurology 1999;53:1431-1438.

3 Dressler D, Dirnberger G: Risk factors for therapy failure. International Conference 1999: Basic and Therapeutic Aspects of Botulinum and Tetanus Toxin, Orlando, 1999, p 80.
4 Pellizzari R, Rossetto O, Schiavo G, Montecucco $\mathrm{C}$ : Tetanus and botulinum neurotoxins: Mechanism of action and therapeutic uses. Philos Trans R Soc Lond B Biol Sci 1999;354: 259-268.

5 Brashear A, Lew MF, Dykstra DD, Comella CL, Factor SA, Rodnitzky RL, Trosch R, Singer C, Brin MF, Murray JJ, Wallace JD, Willmer-Hulme A, Koller M: Safety and efficacy of NeuroBloc (botulinum toxin type B) in type Aresponsive cervical dystonia. Neurology 1999; 53:1439-1446.

6 Gelb DJ, Lowenstein DH, Aminoff MJ: Controlled trial of botulinum toxin injections in the treatment of spasmodic torticollis. Neurology 1989;39:80-84.
7 Poewe W, Deuschl G, Nebe A, Feifel E, Wissel J, Benecke R, Kessler KR, Ceballos-Baumann AO, Ohly A, Oertel W, Kunig G: What is the optimal dose of botulinum toxin A in the treatment of cervical dystonia? Results of a double blind, placebo controlled, dose ranging study using Dysport. German Dystonia Study Group. J Neurol Neurosurg Psychiatry 1998; 64:13-17.

8 Coffield JA, Bakry NM, Maksymowych AB, Simpson LL: Characterization of a vertebrate neuromuscular junction that demonstrates selective resistance to botulinum toxin. J Pharmacol Exp Ther 1999;289:1509-1516. 